\title{
Neighborhood and Community Factors: Effects on Deviant Behavior and Social Competence
}

\author{
Francisca Fariña ${ }^{1}$, Ramón Arce $^{2}$ and Mercedes Novo ${ }^{2}$ \\ ${ }^{1}$ Universidad de Vigo \\ ${ }^{2}$ Universidad de Santiago de Compostela
}

\begin{abstract}
Socialization in a neighborhood and community at risk, defined in terms of violence, social alienation, school failure, and disruptive behavior, is a risk factor for the acquisition of antisocial and delinquent behavior. In order to test this hypothesis and examine the underlying mechanisms involved, 346 participants, 155 high-risk and 191 low-risk, aged 11 to 13 , that is, under the age of criminal responsibility as established by the Spanish Law 5/2000 were selected. The results reveal that high-risk youngsters had higher rates of antisocial behavior and lower levels of social skills (i.e., greater tendency to externalize attribution of responsibility, fewer conflict resolution strategies, lower self esteem, and a lower degrees of emotional intelligence) in comparison to the lower-risk group. Finally, the results and implications of the study are discussed in the light of designing prevention programs.

Keywords: juvenile delinquency, deviant behavior, risk factors, protective factors, resilience
\end{abstract}

La socialización en un vecindario y comunidad de riesgo, definido por la violencia, exclusión social, fracaso escolar y comportamientos disruptivos, es un factor de riesgo para la adquisición de comportamientos antisociales y delictivos (p.e., Farrington, 1996; Lösell y Bender, 2003). Para contrastar esta hipótesis así como los mecanismos subyacentes a la misma, tomamos una muestra de 346, 155 de alto riesgo y 191 de bajo riesgo, participantes de entre 11 y 13 años, es decir, sin responsabilidad penal según la Ley $5 / 2000$. Los resultados mostraron que los jóvenes de un ambiente social de riesgo presentaban mayores tasas de comportamiento antisocial así como una menor competencia social (vs. gr., mayor tendencia a la atribución externa de responsabilidad, menos estrategias de afrontamiento, un autoconcepto más bajo y un menor desarrollo de la inteligencia emocional) en comparación con menores de bajo riesgo social. Finalmente, se discuten los resultados e implicaciones para el diseño e implementación de programas preventivos.

Palabras clave: delincuencia juvenil, comportamiento antisocial, factores de riesgo, factores protectores, prevención, resiliencia

This work was financed by the Secretaría Xeral de Investigación e Desenvolvemento, Xunta de Galicia, Proyecto de Excelencia Investigadora Code PGIDIT03CS037401PR.

Correspondence concerning this article should be addressed to Francisca Fariña, Facultad de Ciencias de la Educación, Avda. de Buenos Aires, s/n, 36002 Pontevedra (Spain). Phone: +34-986-801708. E-mail: francisca@uvigo.es 
The models that have proven to be the most operative and effective for explaining antisocial behavior have two primary objectives: (a) to identify the risk and protective factors, and (b) to design models of social competency or vulnerability. Though both models appear to be divergent, they are complementary. Risk models have identified several variables that predispose an individual to antisocial behavior (Andrews \& Bonta, 1998; Farrington, 1996) such as pre- and peri-natal factors; antisocial or procriminal attitudes and beliefs; temperamental and personality factors such as hyperactivity, impulsiveness, egocentricism, poor problem-solving, and poor self-regulating skills; low intelligence; family history of criminality or poor parental supervision and discipline; broken homes; large families; socioeconomic deprivation; association with procriminal peers; school influences; community and neighborhood influences; low levels of personal, educational, vocational or financial achievement; and contextual variables. On the other hand, protective models profile protective factors (Lösel \& Bender, 2003) such as biological and psychophysiological factors; temperamental and personality traits; cognitive competence; attachment to reference persons; upbringing and educational climate; school achievement, school bonding and employment; social networks and peer groups; self-related cognition, social cognition and beliefs; and neighborhood and community factors. Thus, it appears that some factors have a lineal relation with antisocial behavior whereas others do not. In terms of community and neighborhood factors, the main objective of this study, these may act either as protective or risk factors.

Given that protective or risk factors do not arise in isolation but appear to co-occur, the combination of risk factors has led to the proliferation of vulnerability or skills deficits models (Ross \& Fabiano, 1985; Werner, 1986; Zubin, 1989) whilst protective factors have been associated with competency (Wallston, 1992). Vulnerability or skill deficit models are defined as a set of variables that act jointly and foster antisocial and delinquent behavior. In contrast, a competency model involves the grouping of protective factors that may amplify their effects. The social competence models proposed have been numerous. For example, D'Zurilla (1986) characterizes social competence as a wide range of coping skills and strategies; and Peterson and Leigh (1990) integrate attributional processes, interpersonal skills, and empathy (for a review see, López, Garrido, \& Ross, 2001). In spite of the variations, a common characteristic of these models is that they all encompass a range of cognitive and/or social variables to explain the individual's lack of or proficiency in social competence in response to antisocial and delinquent settings (for an integrative study and model of both see Fariña, Arce, Novo, Seijo, \& Vázquez, 2005).

Bearing in mind the literature regarding protective and risk factors as well as the social competence and vulnerability models, a field study was undertaken to assess the effects of a protective and risk factor (i.e., low vs. high-risk) "community and neighborhood influences" on antisocial and delinquent behavior as well as their effects on the vulnerability or social competence of youngsters under the age of criminal responsibility as established by the Spanish Law 5/2000.

\section{Method}

\section{Participants}

A total of 346 young people aged 10 to 13 , mean age 11.51 years $(S D=1.27)$, were included in the study. Of these, $176(50.87 \%)$ were boys, mean age 11.52 years, and $170(49.13 \%)$ were girls, mean age 11.50 years. One hundred fifty-five (79 boys, mean age 11.7 years, and 76 girls, mean age 11.5 years) lived in a high-risk community, and 191 (97 boys, mean age 11.3 years, and 94 girls, mean age 11.4 years) in a low-risk community, All participants attended state schools and were either in their $6^{\text {th }}$ year of primary education $(n=166)$ or their $1^{\text {st }}$ year of Compulsory Secondary Education (CSE; $n=180$ ).

\section{Procedure and Design}

Data were obtained from individual questionnaires administered simultaneously to all pupils in their classrooms in four schools in Melilla, a Spanish city in North Africa where the risk of antisocial behavior is relatively high. Participants completed a section of a questionnaire designed to assess sociodemographic data, antisocial behavior and delinquency, self-concept, coping strategies, emotional intelligence, and attribution. Participants were selected from four schools; two were defined by the Spanish Public Administration, as a function of its neighborhood/community, as high-risk social deviancy schools, and the other two as low-risk. For each condition, one class of primary education students and one class of $1^{\text {st }}$ year CSE students were selected for study. The research methodology was quasi-experimental and set in a natural setting. The experimental design consisted of a grouping factor "community and neighborhood influences" with two levels, high versus low-risk community/neighborhood, and their impact on a set of variables characteristic of social competency or antisocial and delinquent behavior. The place of residence was chosen as a protective or risk factor as it has been well and consistently documented in the literature that some places are highly linked to the risk of delinquency and antisocial behavior (Farrington, 1996; Loeber \& Farrington, 1998; Loeber, Green, \& Lahey, 2003; Lösel \& Bender, 2003; Robins, Tipp, \& Pryzbeck, 1991).

\section{Measurement Instruments}

The sociodemographic measurement instrument was designed to identify the participants (e.g., level of schooling and academic achievement) as well as social circumstances 
(e.g., number of brothers and sisters, parent's academic achievements, the families' economic status).

Antisocial and Delinquency Scale (AD; Seisdedos, 1995). The evaluation of deviant behavior, measured in terms of antisocial behavior (e.g., breaking bottles and overturning garbage cans) and delinquency (e.g., theft and intimidation, which are offences punishable by law) was carried out using the Antisocial and Delinquency Scale, which is a self-report instrument to measure delinquent and antisocial behavior. The results are the sum of several types of self-reported antisocial and delinquent behavior (scored in a Yes/No format). Antisocial and, in particular, delinquent behavior is presumed to be absent in the general population and even to a greater extent in youngsters below the age of criminal responsibility (> 14 years).

"Autoconcepto Forma-A" (AFA; Musitu, Gracía, \& Gutiérrez, 1997). For the measurement of self-concept, the "Autoconcepto Forma-A" (in Spanish, the Self-concept Questionnaire, Form A), which consists of four components (emotional, social, physical, and academic), was administered. The scores for each factor were calculated by adding the values for each item which ranged from 11-33, 5-15, 9-27, and 6-18 for academic, social, emotional, and family selfconcept, respectively. No gender or age differences were observed in the under-14 age group (Musitu et al., 1997).

Trait Meta-Mood Scale (TMMS; Salovey, Mayer, Goldman, Turkey, \& Palfai, 2002). Emotional intelligence was evaluated with the Trait Meta-Mood Scale, which assess a person's meta-knowledge of emotional intelligence by measuring the ability to perceive feelings, clarity of feelings, and mood repair (repairing unpleasent moods and mantaining pleasent ones). The scale consists of 30 items, 13 of attention, 11 of clarity, and 6 of repairing, and participants respond using a 5-point scale, ranging from 1 (strongly disagree) to 5 (strongly agree). This scale was translated into Spanish and evaluated in terms of internal consistency by Fernández-Berrocal and colleagues (1998) and offered the following results: attention $(\alpha=.87)$ clarity $(\alpha=.81)$, and repair $(\alpha=.76)$.

Adolescent Coping Scale (ACS; Frydenberg \& Lewis, 1996). Coping strategies were measured using the Adolescent Coping Scale. The Spanish adaptation of the instrument evaluates 18 strategies that are grouped into four dimensions: two positive coping strategies (positive coping action and positive hedonist action) and two negative coping strategies (intrapunitiveness and introversion). The frequency of strategy use was ranked as follows: (a) 20-29 = unused strategy; (b) 30-49 = rarely used strategy, (c) 50-69= occasionally used strategy, (d) 70-89 = frequently used strategy, and (e) 90-100 = very frequently used strategy.

Locus of Control Scale (Rotter, 1966). The attributional processes were measured by Rotter's Locus of Control Scale, which evaluates attributional processes on an internal-external continuum. The scale, which was translated into Spanish using the back-translation technique, proved to be reliable for the sample under study $(\alpha=.79)$. This scale consists of one-dimensional 23 items. The cut-off point between internal and external attribution was 11.5 , being below 11.5 for internal attribution, and above 11.5 for external attribution.

Community and neighborhood influences. Finally, the community and neighborhood influences factor (Farrington, 1996; Loeber \& Farrington, 1998; Loeber, Green, \& Lahey, 2003; Robins et al., 1991), was assessed using the classification provided by the Provincial Education Authority of the Autonomous City of Melilla, which is subordinate to the Spanish Ministry of Education, Culture and Sports, and which rates the risk of a neighborhood/community according to official statistics on violent and delinquent behavior, social alienation, school failure, and disruptive behavior in the classroom.

\section{Results}

\section{Deviant Behavior}

A MANOVA analysis revealed significant differences in deviant behavior mediated by the community and neighbourhood influences factor (high vs. low-risk community/neighbourhood), $F(2,328)=11.24, p<.001, \eta^{2}$ $=.064 ; 1-\beta=.992$, which accounts for $6.4 \%$ of the variance. This moderate effect size is probably due to the fact that the younsters are below the age of criminal responsibility $(<14$ years), that is, the cut-off at which the probablity of deviant behavior rises. The univariate effects (see Table 1) show a higher rate of antisocial (e.g., breaking bottles and overturning garbage cans) and delinquent behaviors (that is, offences punishable by law) among youngsters from high-risk in comparison to low-risk communities and neighbourhoods. Thus, community and neighbourhood influences exert a protective role or inversely increase the risk of antisocial and delinquent behavior from an early age.

Table 1

Univariate Effects on Deviant Behavior of the Community and Neighborhood Influences Factor

\begin{tabular}{lccccccc}
\hline Variable & $M S$ & $F(1,312)$ & $p$ & $\eta^{2}$ & $1-\beta$ & $M_{\text {low }}$ & $M_{\text {high }}$ \\
\hline Antisocial & 97.28 & 9.48 & .002 & .028 & .866 & 1.07 & 2.16 \\
Delinquency & 143.98 & 22.52 & .000 & .064 & .997 & 0.26 & 1.58 \\
\hline
\end{tabular}

Note: $M_{\text {low }}=$ mean of the low-risk community and neighborhood group; $M_{\text {high }}=$ mean of the high-risk community and neighborhood group. 


\section{Self-Concept}

The MANOVA results for the community and neighborhood influences factor on self-concept showed a significant multivariate effect, $F(4,339)=7.66, p<.001, \eta^{2}=.083 ; 1-\beta$ $=.997$, which explained $8.3 \%$ of the variance. As for the univariate effects (see Table 2), differences were observed in the four components of self-concept mediated by community and neighborhood factor. That is, youngsters from high-risk neighborhood/community had developed an emotional, social, school, and family self-concept that was not as positive as that of low-risk youngsters. In short, the self-concept of youngsters form high-risk community and neighborhoods fits the "vulnerability hypothesis" (Ross \& Fabiano, 1985; Werner, 1986, Zubin, 1989), whereas that of low-risk youngsters fits the "protection hypothesis" (Wallston, 1992); hence, a positive and robust self-concept protects a person from antisocial and delinquent behavior, whereas a weak one leads to vulnerability.

\section{Coping Strategies}

The results of the MANOVA analysis of the community and neighborhood influences factor on coping strategies showed a significant multivariate effect, $F(18,127)=2.69, p<.001$, $\eta^{2}=.276,1-\beta=1$, which explained $27.6 \%$ of the variance. The univariate effects reveal (see Table 3) differences modulated by the community and neighborhood influences factor in the following coping strategies: working hard, seeking to belong, reducing tension, and physical recreation. Low-risk youngsters tended to use the following positive action coping strategies: working hard, that is, working hard to achieve; seeking to belong, which denotes a concern for others; and physical recreation, which focuses on sports and keeping fit. In contrast, high-risk youngsters resorted to the intrapunitive escape/avoidance strategy reducing tension, aimed at reducing tension by crying, screaming, smoking, or drinking. In short, high-risk youngsters are inclined to use negative coping

Table 2

Univariate Effects on the Self-Concept of the Community and Neighborhood Influences Factor

\begin{tabular}{lccccccc}
\hline Variable & $M S$ & $F(1,342)$ & $p$ & $\eta^{2}$ & $1-\beta$ & $M_{\text {low }}$ & $M_{\text {high }}$ \\
\hline Emotional & 78.36 & 5.33 & .022 & .015 & .634 & 26.57 \\
Social & 56.08 & 16.19 & .000 & .045 & .980 & 13.26 & 12.44 \\
School & 42.67 & 4.51 & .034 & .013 & .563 & 18.45 \\
Family & 246.48 & 7.87 & .005 & .022 & .799 & 16.2 & 17.74 \\
\hline
\end{tabular}

Note: $M_{\text {low }}=$ mean of the low-risk community and neighborhood group; $M_{\text {high }}=$ mean of the high-risk community and neighborhood group.

Table 3

Univariate Effects on Coping Strategies of the Community and Neighborhood Influences Factor

\begin{tabular}{|c|c|c|c|c|c|c|c|}
\hline Variable & $M S$ & $F(1,144)$ & $p$ & $\eta^{2}$ & $1-\beta$ & $M_{\text {low }}$ & $M_{\text {high }}$ \\
\hline Social support & 587.58 & 2.03 & .157 & .014 & .293 & 67.21 & 72.25 \\
\hline Problem solving & 986.43 & 3.68 & .057 & .025 & .478 & 65.84 & 72.36 \\
\hline Work hard & 2088.52 & 10.33 & .002 & .067 & .891 & 62.75 & 82.24 \\
\hline Worrying & 45.34 & .19 & .668 & .001 & .071 & 75.8 & 77.2 \\
\hline Investing in friends & 69.82 & .23 & .634 & .002 & .076 & 72.3 & 74.03 \\
\hline Seeking to belong & 1249.72 & 5.51 & .020 & .037 & .645 & 69.33 & 76.67 \\
\hline Wishful thinking & 238.11 & 1.17 & .281 & .008 & .189 & 68.95 & 72.15 \\
\hline Not coping & 102.68 & .57 & .453 & .004 & .116 & 48.68 & 46.58 \\
\hline Reducing tension & 1492.19 & 7.35 & .008 & .049 & .768 & 47.62 & 39.6 \\
\hline Social action & 541.04 & 1.84 & .177 & .013 & .271 & 55.54 & 50.71 \\
\hline Ignoring the problem & 189.21 & .62 & .402 & .004 & .123 & 50.57 & 47.71 \\
\hline Self-blame & 131.03 & .71 & .403 & .005 & .133 & 50.32 & 47.94 \\
\hline Keeping to oneself & 46.15 & .19 & .662 & .001 & .072 & 52.59 & 54 \\
\hline Seeking spiritual support & 392.85 & 1.23 & .269 & .008 & .197 & 66.28 & 62.16 \\
\hline Focusing on positive & 526.3 & 2.47 & .118 & .017 & .345 & 73.99 & 78.76 \\
\hline Seeking professional help & 994.4 & 2.29 & .133 & .016 & .324 & 68.21 & 74.76 \\
\hline Relaxation & 3.24 & .01 & .917 & .000 & .051 & 80.49 & 80.87 \\
\hline Physical recreation & 1797.7 & 4.5 & .036 & .030 & .559 & 74.28 & 83.08 \\
\hline
\end{tabular}

Note: $M_{\text {low }}=$ mean of the low-risk community and neighborhood group; $M_{\text {high }}=$ mean of the high-risk community and neighborhood group. 
strategies, that is, "intrapunitive escape/avoidance" (reducing tension), whereas low-risk youngsters employ "positive action" strategies (working hard, seeking to belong, and physical recreation).

\section{Emotional Intelligence}

A MANOVA with the factor community and neighborhood influence and emotional intelligence as the dependent variable was performed, which reported multivariate differences, $F(3,310)=9.35, p<.001 ; \eta^{2}=$ $.083 ; 1-\beta=.997$, explaining $8.3 \%$ of the variance. As for the univariate effects (see Table 4), the data revealed differences in the three components of emotional intelligence. In particular, the differences in attention to feelings highlight that high-risk youngsters paid less attention to emotions or feelings. Likewise, high-risk youngsters appeared to have less clarity of feelings, that is, less insight into their own emotional states. Moreover, in comparison to low-risk youngsters, high-risk youngsters were not as competent in repairing their moods. Consequently, high-risk youngsters were less skillful at evaluating, expressing, and controlling their emotions.

\section{Attributional Processes}

An ANOVA showed significant differences in attributional processes mediated by the community and neighborhood influences factor, $F(1,312)=69.68, p<.001$, $\eta^{2}=.183,1-\beta=1.0$. Thus, high-risk youngsters were inclined to external attribution $(M=13.2)$ in comparison to low-risk youngsters $(M=10.6)$. This factor explained $18.3 \%$ of the attributional processes.

\section{Discussion}

It should be pointed out that the present study entails several limitations. First, the data were obtained exclusively from self-reports which, in the risk group in particular, may contain distortions (i.e., socially desirable responses). Second, the results cannot be generalized entirely and directly to other contexts, given the peculiarities of the context under study (i.e., a multicultural context: Spaniards and Arabs).
Third, the study assumes a linear relationship between dependent variables and risk, but this does not exclude the possibility of other relationships.

Bearing in mind the above safeguards the following conclusions may be drawn:

Community and neighbourhood influences and deviant behavior. Sujects from high-risk community/neighbourhood exhibited more deviant behavior both in terms of antisocial and delinquent behavior well before the age of criminal responsibility (set at the age of 14 years under Spanish law), accounting for $6.4 \%$ of the variance, which increases their predisposition to a life of crime (Moffitt, 1993; Rodríguez \& Paíno, 1994).

Competence/vulnerability. High-risk youngsters exhibited deficits in self-concept, attributional processes, coping strategies, and emotional intelligence, which hinder the development of their social competence, making them more vulnerable (D'Zurilla, 1986; Peterson \& Leigh, 1990) to embark on a "criminal career" (Andrews \& Bonta, 1998; McGuire, 2000). Socialization in a high-risk community/neighborhood not only predisposes youngsters to deviant behavior but also impedes the development of socio-cognitive protective factors (i.e., internal attribution, positive coping strategies, positive high self-concept). In contrast, the low-risk communities/neighborhoods act as a protective factor by encouraging pro-social learning through the acquisition of social skills.

Additive/accumulative model. The results support an additive/accumulative risk/protection model (McGuire, 2000). Indeed, all of the socio-cognitive variables measured underscored differences between high- and low-risk youngsters and the potential of the accumulative or additional profile of high-risk youngsters driven toward antisocial behavior and delinquency. An underling assumption of these models is that the greater the number of risk factors, the higher the probability of deviant behavior. Alternatively, it may be argued, and our data supports this view, that the greater the number of additive or accumulative protective factors, the lower the risk of deviant behavior (Lösel, Kolip, \& Bender, 1992).

Implications for intervention programs. In the light of our results, a primary concern is the role of intervention programs designed to prevent or curtail deviant behavior. Farrington's (2003) review of the literature has revealed that psychosocial intervention and prevention was effective.

Table 4

Univariate Effects on Emotional Intelligence of the Community and Neighborhood Influences Factor

\begin{tabular}{lccccccc}
\hline Variable & $M S$ & $F(1,283)$ & $p$ & $\eta^{2}$ & $1-\beta$ & $M_{\text {low }}$ & $M_{\text {high }}$ \\
\hline Attention to feelings & 1334.99 & 27.42 & .000 & .081 & .999 & 40.41 \\
Clarity of feelings & 172.38 & 4.49 & .035 & .014 & .560 & 35.95 & 37.57 \\
Mood repair & 119.62 & 7.2 & .008 & .023 & .762 & 20.32 & 21.56 \\
\hline
\end{tabular}

Note: $M_{\text {low }}=$ mean of the low-risk community and neighborhood group; $M_{\text {high }}=$ mean of the high-risk community and neighborhood group. 
Assuming that intervention is both viable and effective, a second aspect to be considered is the objectives and scope of these programs. According to an integrative approach of models proposed by Arce and Fariña (1996, 2005), the findings underline the need for joint multimodal and multilevel approaches. By multimodal approach, we refer to the different complementary courses of action (e.g., cognitive and behavioral). Multilevel approaches emphasize that intervention programs should not focus exclusively on high-risk youngsters, which is common practice in most programs, but should encompass all settings, such as family, school, and other relevant social scenarios. The partial solutions offered by additive or accumulative models may stem the risk of deviant behavior but cannot eradicate it. Hence, intervention programs for youngsters at risk should deal with all spheres of social competence (e.g., self-concept and emotional intelligence), which should be accompanied by complementary community support programmes (i.e., family, school, and neighborhood).

Finally, the socialization of younsters in high-risk community and neigborhoods entails skill deficits which in turn leads to greater vulnerability to deviancy and delinquency at an early age (i.e., prior to the age of criminal responsibility).

\section{References}

Andrews, D.A., \& Bonta, J. (1998). The psychology of criminal conduct ( $2^{\text {nd }}$ ed.). Cincinnati, $\mathrm{OH}$ : Anderson.

Arce, R., \& Fariña, F. (1996). From jurors to jury decision making. A non-model approach. In G. Davis, M. McMurran, C. Wilson, \& S. Lloyd-Bostock (Eds.), Psychology, law and criminal justice. International developments in research and practice (pp. 337-343). Berlin: Walter de Gruyter

Arce, R., \& Fariña, F. (2005). Modelos explicativos robustos del comportamiento delictivo e implicaciones para la intervención. Temas Penitenciarios, III, 17-22.

D’Zurilla, T.J. (1986). Problem-solving therapy. A social competence approach to clinical interventions. New York: Springer Verlag.

Fariña, F., Arce, R., Novo, M., Seijo, D., \& Vázquez, M.J. (2005). Estudio de la incidencia de las variables psicosociales y cognitivas en el comportamiento antisocial dentro del contexto escolar. In Centro de Investigación y Documentación Educativa (Ed.), Premios nacionales de investigación educativa 2003 (pp. 127-155). Madrid: Ministerio de Educación y Ciencia.

Farrington, D.P. (1996). Understanding and preventing youth crime. New York: Joseph Rowntree Foundation.

Farrington, D.P. (2003). Advancing knowledge about the early prevention of adult antisocial behavior. In D.P. Farrington \& J.W. Coid (Eds.), Early prevention of antisocial behavior (pp. 1-31). Cambridge, UK: Cambridge University Press.

Fernández-Berrocal, P., Alcaide, R., Domínguez, E., FernándezMcNally, C., Ramos, N. S., \& Ravira, M. (1998, April-May). Adaptación al castellano de la escala Rasgo de Metaconocimiento sobre Estados Emocionales de Salovey et al.: datos preliminares. V Congreso de Evaluación Psicológica, Málaga (Spain).

Frydenberg, E., \& Lewis, R. (1996). The Adolescent Coping Scale: Multiple forms and applications of a self report inventory in a counselling and research context. European Journal of Psychological Assessment, 12, 216-227. (Spanish translation: Escalas de afrontamiento para adolescentes [ACS]. Madrid: TEA, 2000).

Loeber, R., \& Farrington. D.P. (Eds.). (1998). Serious and violent juvenile offenders: Risk factors and successful interventions. Thousand Oaks, CA: Sage.

Loeber, R., Green, S., \& Lahey, B. (2003). Risk factors for adult personality. In D.P. Farrington \& J.W. Coid (Eds.), Early prevention of antisocial behavior (pp. 79-108). Cambridge, UK: Cambridge University Press.

López, M.J., Garrido, VS., \& Ross, R.R. (2001). El programa del pensamiento prosocial: Avances recientes. Valencia: Tirant lo Blanch.

Lösel, F., \& Bender, D. (2003). Protective factors and resilience. In D.P. Farrington \& J.W. Coid (Eds.), Early prevention of antisocial behavior (pp. 130-204). Cambridge, UK: Cambridge University Press.

Lösel, F., Kolip, P., \& Bender, D. (1992). Stress-resistance in a multiproblem milieu: Are resilient juveniles "Superkids"? Zeitschrift für Klinische Psychologie, 21, 48-63.

McGuire, J. (2000). Explanations of criminal behavior. In J. McGuire, T. Mason, \& A. O'Kane (Eds.), Behavior, crime and legal processes. A guide for forensic practitioners (pp. 135159). Chichester, UK: John Wiley \& Sons.

Moffitt, T.E. (1993). Adolescence-limited and life-course-persistent antisocial behavior: A developmental taxonomy. Psychological Review, 100, 674-701.

Musitu, G., Gracía, F., \& Gutiérrez, M. (1997). AFA. Autoconcepto. Forma A: Autoconcepto académico, social, emocional y familiar. Madrid: TEA.

Peterson, G.W., \& Leigh, G.K. (1990). The family and social competence in adolescence. In T.P. Gullotta, G.R. Adams, \& R. Montemayor (Eds.), Developing social competence in adolescence. Advances in adolescent development (Vol. 3, pp. 97-139). Thousand Oaks, CA: Sage.

Robins, L.N., Tipp, J., \& Pryzbeck, T. (1991). Antisocial personality. In L.N. Robins \& D.A. Regier (Eds.), Psychiatric disorders in America (pp. 224-271). New York: Free Press.

Rodríguez, F.J., \& Paíno, S.G. (1994). Violencia y desviación social: bases y análisis para la intervención. Psicothema, 6 , 229-244.

Ross, R.R., \& Fabiano, E.A. (1985). Time to think: A cognitive model of delinquency prevention and offender rehabilitation. Johnson City, TN: Institute of Social Sciences and Arts Inc.

Rotter, J.B. (1966). Generalized expectancies of internal versus external control of reinforcement. Psychological Monographs, 80 (Whole Hr. 609).

Salovey, P., Mayer, J.D., Goldman, S.L., Turkey, C., \& Palfai, T.P. (2002). Emotional attention, clarity, and repair: Exploring emotional intelligence using the Trait Meta-Mood Scale. In 
J.W. Pennebaker (Ed.), Emotion, disclosure, and health $\left(3^{\text {rd }}\right.$ ed., pp. 125-154). Washington, DC: American Psychological Association.

Seisdedos, N. (1995). Cuestionario A-D (conductas antisocialesdelictivas). Madrid: TEA.

Wallston, K.A. (1992). Hocus-pocus, the focus isn't strictly on locus: Rotter's social learning theory modified for health. Cognitive Therapy and Research, 16, 183-199.
Werner, E.E. (1986). The concept of risk from a developmental perspective. Advances in Special Education, 5, 1-23.

Zubin, J. (1989). Suiting therapeutic intervention to the scientific models of aetiology. British Journal of Psychiatry, 115, 9-14.

Received October, 17, 2006 Revision received October, 18, 2007 Accepted October, 27, 2007 